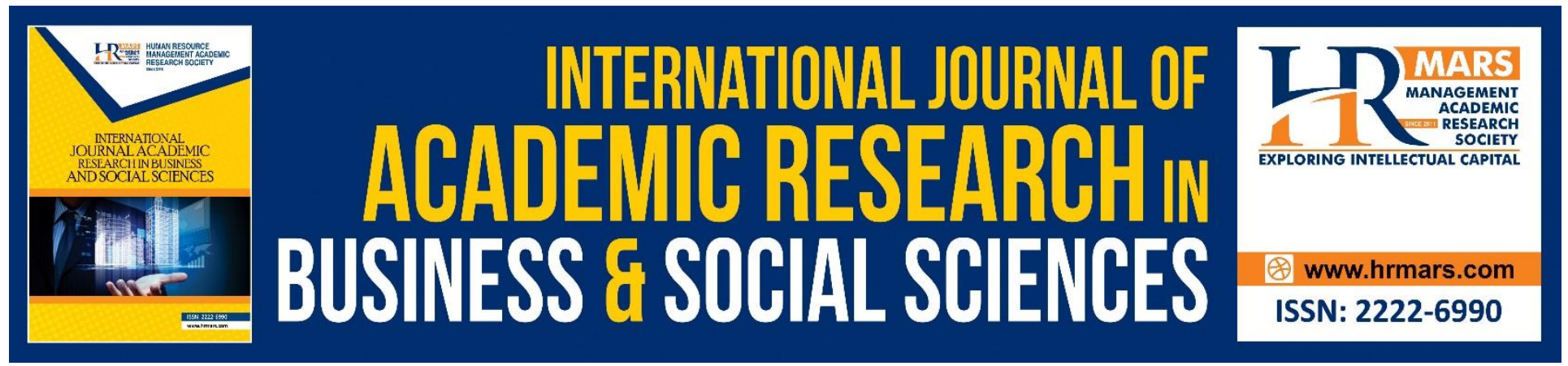

\title{
The Relationship between Public Expenditure for Technical and Vocational Education and Employability Skills of the Graduates of Vocational Colleges in Malaysia
}

\section{Enah Ali, Ridzuan Che' Rus, Mohd Ridwan Abd Razak}

To Link this Article: http://dx.doi.org/10.6007/IJARBSS/v8-i8/4633

DOI: $\quad 10.6007 /$ IJARBSS/v8-i8/4633

Received: 24 June 2018, Revised: 22 July 2018, Accepted: 29 July 2018

Published Online: 23 August 2018

In-Text Citation: (Ali, Rus, \& Razak, 2018)

To Cite this Article: Ali, E., Rus, R. C., \& Razak, M. R. A. (2018). The Relationship between Public Expenditure for Technical and Vocational Education and Employability Skills of the Graduates of Vocational Colleges in Malaysia. International Journal of Academic Research in Business and Social Sciences, 8(8), 790-800.

\section{Copyright: (c) 2018 The Author(s)}

Published by Human Resource Management Academic Research Society (www.hrmars.com)

This article is published under the Creative Commons Attribution (CC BY 4.0) license. Anyone may reproduce, distribute, translate and create derivative works of this article (for both commercial and non-commercial purposes), subject to full attribution to the original publication and authors. The full terms of this license may be seen at: http://creativecommons.org/licences/by/4.0/legalcode

Vol. 8, No. 8, August 2018, Pg. 790 - 800

Full Terms \& Conditions of access and use can be found at http://hrmars.com/index.php/pages/detail/publication-ethics 


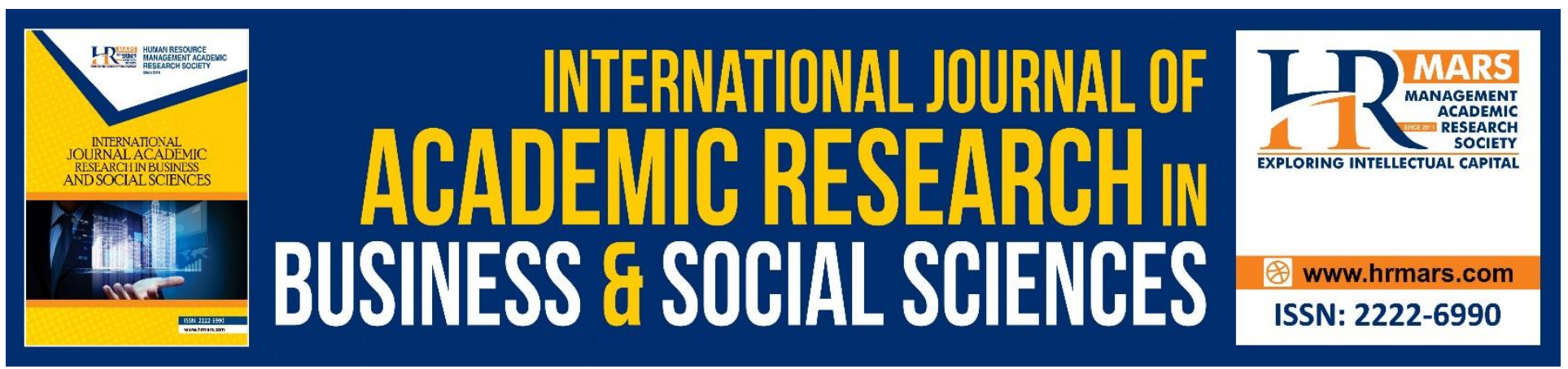

\title{
The Relationship between Public Expenditure for Technical and Vocational Education and Employability Skills of the Graduates of Vocational Colleges in Malaysia
}

\author{
Enah Ali \\ Faculty of Technical and Vocational Education, Sultan Idris Education University \\ Malaysia \\ Ridzuan Che' Rus \\ Faculty of Technical and Vocational Education, Sultan Idris Education University \\ Malaysia
}

\section{Mohd Ridwan Abd Razak}

Graduate School of Business, National University of Malaysia

Malaysia

\section{Abstract}

Public expenditure for technical and vocational education is important for Malaysia to produce high skilled workers to achieve the status of a developed and high-income country by the year 2020. The objective of this study is to measure the relationship between public expenditure for technical and vocational education and employability skills of the graduates of vocational colleges in Malaysia. The SmartPLS path model analysis revealed two important findings: first, recurrent expenditure was significantly correlated with employability skills. Second, development expenditure was significantly correlated with employability skills. These outcomes demonstrate that the ability of technical and vocational education administrator to provide and manage adequate financial allocation may lead to enhance graduate's employability skills. In addition, discussion, implications and conclusion are described.

Keywords: Public Expenditure, Recurrent Expenditure, Development Expenditure, Employability Skills of the Graduates, Malaysia

Introduction

Public expenditure in education and training is an important issue in an era of knowledge based economy (k-economy). It was argued by many scholar in various fields such as education (Harris, Chisholm \& Burns, 2013; Shirley, 2017), human resource management (Bornemann \& Wiedenhofer, 
INTERNATIONAL JOURNAL OF ACADEMIC RESEARCH IN BUSINESS AND SOCIAL SCIENCES Vol. 8, No. 8, August 2018, E-ISSN: 2222-6990 @ 2018 HRMARS

2014; Ognjanović, 2016) and training and development (Alagaraja \& Arthur-Mensah, 2013; Nafukho, 2013). Based on education perspective, public expenditure for technical and vocational education is commonly observed as a combination of recurrent and development expenditure organized by government to provide adequate education and training facilities in order to produce high skilled workers. (Adamson, Åstrand \& Darling-Hammond, 2016; Adetula, Adesina, Owolabi \& Stephen, 2017; Fan, Ma \& Wang, 2015).

An analysis of recent literature about public expenditure for education, highlights that public expenditure for technical and vocational education consist of two important elements: recurrent expenditure and development expenditure (Bateman, Brown \& Uera, 2015; Bateman, Cassity \& Fangalasuu, 2015; Maglen, Wall \& Rokovunisei, 2015). According to several scholar such as Bateman, Brown and Uera (2015) and Bateman, Cassity and Fangalasuu (2015), recurrent expenditure mostly defined as any payment for goods and services which needed to be made recurrently to sustain the delivery of educational services such as wages and salaries, subsidies, utilities and teaching materials. Further, development expenditure is generally viewed as any payment to provide education facilities such as cost for construction, renovation and repair of buildings, purchase of vehicles and heavy learning equipment (Chude \& Chude, 2013; Devkota, Chaulagain \& Bagale, 2016; Jones, Sutcliffe, Bragg \& Harris, 2016).

Surprisingly, a careful observation of newest research literature about public expenditure for education exposes that government expenditure for technical and vocational education (i.e., recurrent expenditure and development expenditure) may have a significant impact on graduate's employability skills (Ismail \& Mohammed, 2015; Kemmis, Hodge \& Bowden, 2014; Maclean \& Jagannathan, 2014). Based on training and development perspective, employability skills is often defined as an essential abilities needed by an individual to qualify them for employment and success in the workplace (Benson, Morgan \& Filippaios, 2014; Ismail \& Mohammed, 2015; Silva, Almeida \& Strokova, 2015). As a result, this relationship may enhance graduate's employability skills and to make them employable (Ahmad, Kenayathulla \& Idris, 2017; Moses, 2017; Rao, 2014).

Within public expenditure for education model, numerous scholars agreed that recurrent expenditure, development expenditure and employability skills are distinct constructs, but highly interconnected. For instance, Krskova \& Baumann (2017), Ayiro (2015) and Gamlath (2013) found that public expenditure for education may enhance graduate's education performance, specifically in terms of graduate's achievement in examination. Further, research conducted by Yang \& Huang (2017) and Panda (2015) shows that public expenditure for education may increase employee's income because they were equipped with adequate skill and knowledge needed by the industries. Hence, this situation may enhance organizational competitiveness in the era of Fourth Industrial Reolution. In addition, Ismail and Mohammed (2015), Kemmis, Hodge and Bowden (2014) and Maclean and Jagannathan (2014) showed that the capability of administrators to appropriately provide and manage technical and vocational education expenditure (i.e., recurrent and development expenditure) may enhance graduate's employability skills. Although the nature of this relationship is significant, little is known about the role of public expenditure for technical and vocational education as an important determinant of graduate's employability skills in the technical and vocational education research literature. Thus, it encourage the researchers to further discover the true nature of this relationship. 
INTERNATIONAL JOURNAL OF ACADEMIC RESEARCH IN BUSINESS AND SOCIAL SCIENCES

Vol. 8, No. 8, August 2018, E-ISSN: 2222-6990 @ 2018 HRMARS

\section{Literature Review}

According to Becker's (1993), human capital theory explains that training and education is an important investment to produce high skilled workers. This theory also stressed that high skilled workers is an important instrument for organizational productivity improvement and economic development. This idea gained strong support from the technical and vocational education research literature. For instance, numerous recent studies were conducted using a direct effects model to evaluate the effects of public expenditure for technical and vocational education based on different samples, such as perceptions of 111 graduates from Faculty of Technical and Vocational Education, Sultan Idris Education University (Ridzwan, Malik, Hanapi, Mohamed, Hussain \& Shahrudin, 2017), 305 employers from India (Jeswani, 2016) and interviewed with TVET experts from private sector (Lee \& Ogawa, 2016). These studies verified that public expenditure for technical and vocational education may strongly enhance technical and vocational graduates employability skills, in terms of core skills and soft skills (Jeswani, 2016; Lee \& Ogawa, 2016; Ridzwan, Malik, Hanapi, Mohamed, Hussain \& Shahrudin, 2017).

Further, studies conducted by Ismail \& Mohammed (2015), Maclean \& Jagannathan (2014) and Esa \& Abdul Rahman (2014), revealed that public expenditure for technical and vocational education may help to equipped technical and vocational graduates with employability skills needed by modern industries in 21st century. This finding has supported by Mulongo, Kitururu \& Irira (2016) and Webster \& Sausner (2017), which exposed that public expenditure for technical and vocational education may enhance opportunities for youth and community development in line with 4th industrial revolution. While, studies conducted by Pavlin \& Svetlik (2014) and Taremwa (2017), shows that the ability of technical and vocational education programmes to produce skilled workers in labour market may enhance organization's productivity and competitiveness in an era of globalization, as well as may help to accelerate the development of national economy. Thus, is was hypothesized that:

$\mathrm{H} 1$ : Recurrent expenditure positively related to employability skills.

H2: Development expenditure positively related to employability skills.

\section{Purpose Of The Study}

This study has two main objectives: first, to examine the relationship between recurrent expenditure and employability skills. Second, to examine the relationship between development expenditure and employability skills.

\section{Methodology}

\section{Research Design}

This study employed a cross-sectional research design which allowed the researchers to integrate the public expenditure for education literature and the actual survey as a means to collect data for this study. Using this data collection procedure will help the researchers gather accurate data, decrease bias and increase quality of data being collected (Cresswell, 1998; Sekaran \& Bougie, 2010). This study was conducted at agriculture vocational college under Ministry of Higher Education Malaysia. At the early stage of this study, a survey questionnaire was drafted based on the public expenditure for education research literature. Then, a back translation method was used to translate the survey questionnaires into English and Malay versions in order to increase the validity and reliability of research findings (Cresswell, 1998; Sekaran \& Bougie, 2010). 
INTERNATIONAL JOURNAL OF ACADEMIC RESEARCH IN BUSINESS AND SOCIAL SCIENCES

Vol. 8, No. 8, August 2018, E-ISSN: 2222-6990 @ 2018 HRMARS

\section{Measures}

The survey questionnaire consists of three parts: first, recurrent expenditure had 6 items adapted from the investment in education literature (Adekola, 2014; Loxley, Seery \& Walsh, 2014; Simanaviciene, Giziene, Jasinskas \& Simanavicius, 2015). Second, development expenditure had 6 items adapted from the investment in education literature (Adekola, 2014; Adetula, Adesina, Owolabi \& Stephen, 2017). Finally, employability skills had 33 items adapted from the training and development literature (de Guzman \& Choi, 2013; Jackson, 2014; York, Gibson \& Rankin, 2015). All these items were measured using a 5-item scale ranging from "strongly disagree/dissatisfied" (1) to "strongly agree/satisfied" (5). Demographic variables were used as controlling variables because this study emphasized on employee attitudes.

\section{Sample}

This study employed a convenient sampling technique to collect 138 usable survey questionnaires from final year graduates studied at agriculture vocational college in peninsular Malaysia. This sampling technique was applied because the management of the college had not given the list of registered graduates to the researchers and this situation did not allow the researchers to use a random technique in choosing respondents for this study. The survey questionnaires were answered by participants based on their consent and on a voluntary basis.

\section{Data Analysis}

The SmartPLS was used to assess the validity and reliability of the instrument and test the research hypotheses. The main advantages of using this method may deliver latent variable scores, avoid small sample size problems, estimate every complex model with many latent and manifest variables, hassle stringent assumptions about the distribution of variables and error terms, and handle both reflective and formative measurement models (Henseler \& Chin., 2010, Ringle et al., 2010). The SmartPLS path model was employed to assess the path coefficients for the structural model using the standardized beta $(\beta)$ and t statistics. The value of R2 is used as an indicator of the overall predictive strength of the model. The value of R2 is considered as follows: 0.19 (weak), 0.33 (moderate) and 0.67 (substantial) (Henseler \& Chin, 2010). As an additional assessment of model fit in PLS analysis, we carried out a test of predictive relevance using blindfolding (Q2 statistic) as suggested by Geisser (1975) and Stone (1974). According to Chin (2001), the Q2 statistic is a jackknife version of the R2 statistic. It represents a measure of how well observed values are reconstructed by the model and its parameter estimates. Models with Q2 greater than zero are considered to have predictive relevance. The value of Q2 is considered as follows: 0.02 (small predictive relevance for an endogenous construct), 0.15 (medium predictive relevance for an endogenous construct), and 0.35 (large predictive relevance for an endogenous construct) (Hair, Hult, Ringle, \& Sarstedt, 2016).

\section{Findings}

From the sample profile, majority of respondents were Malay (96\%), males (61\%), taking plant agroindustry programme (16\%), and household income less than RM1000 per month (27\%).

Table 1 shows the factor loadings and cross loadings for different constructs. The correlation between items and factors had higher loadings than other items in the different concepts, as well as the loadings of variables were greater than 0.70 in their own constructs in the model are considered adequate (Henseler et al., 2010). Overall, the validity of the measurement model met the criteria. The values of composite reliability for all constructs were greater than 0.80 , indicating that the 
INTERNATIONAL JOURNAL OF ACADEMIC RESEARCH IN BUSINESS AND SOCIAL SCIENCES Vol. 8, No. 8, August 2018, E-ISSN: 2222-6990 @ 2018 HRMARS

instrument used in this study had high internal consistency (Henseler \& Chin, 2010; Nunally \& Bernstein, 1994).

Table 1. The Results of Factor Loadings and Cross Loadings for Different Constructs and Composite Reliability

\begin{tabular}{|c|c|c|c|c|c|}
\hline Construct & $\begin{array}{c}\text { No. Of } \\
\text { Item }\end{array}$ & \multicolumn{3}{|c|}{ Cross Factor Loading } & $\begin{array}{c}\text { Composite } \\
\text { Reliability }\end{array}$ \\
\cline { 3 - 5 } & 33 & $\begin{array}{c}0.706 \text { to } \\
0.858\end{array}$ & & 2 & 0.980 \\
\hline Employability Skills & 3 & & 0.700 to & & 0.900 \\
\hline Recurrent & 6 & & & $\begin{array}{c}0.726 \text { to } \\
0.875\end{array}$ & 0.920 \\
\hline $\begin{array}{c}\text { Expenditure } \\
\text { Development } \\
\text { Expenditure }\end{array}$ & 6 & & & \\
\hline
\end{tabular}

Table 2 shows the results of convergent and discriminant validity analysis. All constructs had the values of AVE larger than 0.5, indicating that they had met the acceptable standard of convergent validity (Barclays et al., 1995; Fornell \& Larcker, 1981; Henseler \& Chin, 2010). In addition, all constructs had values of VAVE in diagonal that were greater than the squared correlation with other constructs in off diagonal, showing that all constructs met the acceptable standard of discriminant validity (Henseler, Ringle \& Sinkovics, 2009).

Table 2. The Results of Convergent and Discriminant Validity Analysis

\begin{tabular}{|c|c|c|c|c|}
\hline Construct & AVE & $\begin{array}{c}\text { Recurrent } \\
\text { Expenditure }\end{array}$ & $\begin{array}{c}\text { Development } \\
\text { Expenditure }\end{array}$ & $\begin{array}{c}\text { Employability } \\
\text { Skills }\end{array}$ \\
\hline Employability Skills & 0.594 & $\mathbf{0 . 7 7 1}$ & & \\
\hline $\begin{array}{c}\text { Recurrent } \\
\text { Expenditure }\end{array}$ & 0.601 & 0.750 & $\mathbf{0 . 7 7 5}$ & \\
\hline $\begin{array}{c}\text { Development } \\
\text { Expenditure }\end{array}$ & 0.658 & 0.682 & 0.677 & $\mathbf{0 . 8 1 1}$ \\
\hline
\end{tabular}

\section{Analysis of the Constructs}

Table 3 shows the results of Collinearity and Descriptive Statistics. The means for all constructs were from 4.000 to 4.191 , signifying that a majority of respondents perceived the levels of recurrent expenditure, development expenditure and employability skills range from high (4) to highest level (5) in the organization. While the values of variance inflation factor for the relationship between the independent variable (i.e. recurrent expenditure and development expenditure) and the dependent variable (i.e. employability skills) was less than 5.0 , signifying that the data was not affected by serious collinearity problems (Hair et al., 2016). These results further confirm that the instrument used in this study has met the acceptable standards of validity and reliability analysis. 
INTERNATIONAL JOURNAL OF ACADEMIC RESEARCH IN BUSINESS AND SOCIAL SCIENCES Vol. 8, No. 8, August 2018, E-ISSN: 2222-6990 @ 2018 HRMARS

Table 3. The Results of Collinearity and Descriptive Statistics

\begin{tabular}{|c|c|c|c|}
\hline Construct & Mean & Standard Deviation & Variance Inflation Factor \\
\hline Employability Skills & 4.191 & .460 & 1.845 \\
\hline $\begin{array}{c}\text { Recurrent } \\
\text { Expenditure }\end{array}$ & 4.083 & .451 & 1.845 \\
\hline $\begin{array}{c}\text { Development } \\
\text { Expenditure }\end{array}$ & 4.000 & .682 & \\
\hline
\end{tabular}

\section{Outcomes of Testing Hypotheses 1 and 2}

Table 4 shows that the inclusion of recurrent expenditure and development expenditure in the analysis had explained 62 percent of the variance in the dependent variable. Specifically, the results of testing the research hypothesis showed two significant findings: first, recurrent expenditure is significantly correlated with employability skills $(\beta=0.532 ; t=3.988)$, thus $\mathrm{H} 1$ is supported. Second, development expenditure is significantly correlated with employability $(\beta=0.323 ; t=2.423)$, thus $\mathrm{H} 2$ is supported. Therefore, the result confirms that recurrent expenditure and development expenditure are an important determinant of employability skills.

Table 4. The Outcomes of Hypotheses 1 and 2

\begin{tabular}{|c|c|c|c|c|}
\hline Hypothesis & Relationship & $\beta$ Value & t Value & $\mathrm{R}^{2}$ \\
\hline $\mathrm{H} 1$ & $\begin{array}{c}\text { Recurrent Expenditure } \\
\rightarrow \text { Employability Skills }\end{array}$ & 0.532 & 3.988 & \multirow{2}{*}{0.62} \\
\hline $\begin{array}{c}\text { Development } \\
\text { Expenditure } \rightarrow \\
\text { Employability Skills }\end{array}$ & 0.323 & 2.423 & \\
\hline
\end{tabular}

Note: Significant at $*_{t}>1.96$

A test of predictive relevance for the reflective endogenous latent variable was further conducted based on Stone-Geisser's Formula: q2=Q2included-Q2excluded/1-Q2 included=0. The value of $Q^{2}$ 0.324, indicating that it was greater than zero for the reflective endogenous latent variable. This result has predictive relevance.

\section{Conclusion}

The results of this study validate that public expenditure for technical and vocational education has strong connection with graduates employability skills in the studied college. In the perspective of this study, majority of the respondents view that the levels of recurrent expenditure, development expenditure and employability skills are high. This situation indicates that the ability of technical and vocational education administrator to provide sufficient financial allocation (recurrent expenditure and development expenditure) may help to enhance graduate's employability skills in line with organization needs. Further, this strategy will make them employable and continue to succeed in their career.

This study offers three important implications: firstly implication to the theoretical contribution. The findings of this study have provided great potential for understanding the influence of recurrent expenditure and development expenditure in strengthening graduate's employability skills in the agriculture vocational college in Malaysia. This findings has supported and extended studies by previous scholars such as Gillies (2017), Kalfa \& Taksa (2015) Pavlin \& Svetlik (2014) and Velasco (2014). Secondly, implication to the robustness of research methodology. The constructs and 
INTERNATIONAL JOURNAL OF ACADEMIC RESEARCH IN BUSINESS AND SOCIAL SCIENCES

Vol. 8, No. 8, August 2018, E-ISSN: 2222-6990 @ 2018 HRMARS

items used in this study had satisfactorily met the standards of validity and reliability analyses. Therefore, this study may lead to produced accurate and reliable research findings.

Thirdly, implication to the practical contribution. The findings of this study can be used as a useful strategies by administrators to enhance the effectiveness of technical and vocational education financial allocation. This objective may successfully achieved if the technical and vocational education management team emphasizes on the following key points: firstly, the factors influencing the effectiveness of technical and vocational education financial allocation should be identified properly in line with the current situation. Improvement in this feature may help technical and vocational education administrator to empower financial allocation and management to achieve technical and vocational education's objectives in producing skills workers. Secondly, public expenditure for technical and vocational education should be used as an important instrument to develop graduate's potential and talent. For example, administrator need to identify graduate's needs, provide material and moral support in building graduate's capability, and suggest unconventional ways to improve graduate's competency in the workplace. If these recommendations are deeply considered this may help to produce more skilled workforce in line with industrial needs in the era of 4 th industrial revolution.

This study confirms that public expenditure for technical and vocational education (i.e., recurrent and development expenditure) has a significant impact on graduates employability skills. This finding has also supported and extended public expenditure for education research literature, mostly published in western. Consequently, current research and practice about public expenditure in education model needs to consider the recurrent and development expenditure as important driving forces in education domain. This study further suggests that the capability of administrator to appropriately provide and manage financial allocation in education will strongly enhance graduate's potential (e.g., core skills, soft skills, metacognition skills and self-efficacy). Further, these positive outcomes may lead to maintain and supported organization's and national's competitiveness in an era of borderless world.

\section{Acknowledgement}

We would like to thank the Ministry of Education, Malaysian for supporting this study.

\section{Corresponding Author}

Enah Ali

Faculty of Technical and Vocational Education, Sultan Idris Education University, Malaysia

Email: edwan01@yahoo.com.my

\section{References}

Adamson, F., Åstrand, B., \& Darling-Hammond, L. (2016). Global education reform: How privatization and public investment influence education outcomes. New York: Routledge.

Adekola, A. (2014). Public investment in human capital and economic growth in Nigeria: Analysis on regime shifts. Journal of Economics and Development Studies, 2(2), 213-231.

Adetula, D., Adesina, K., Owolabi, F., \& Stephen, O. (2017). Investment in Education for the Nigerian Economic Development. Journal of Internet Banking and Commerce, 22(1): 1-15.

Adetula, D., Adesina, K., Owolabi, F., \& Stephen, O. (2017). Investment in Education for the Nigerian Economic Development. Journal of Internet Banking and Commerce, 22(1). 1-15. 
INTERNATIONAL JOURNAL OF ACADEMIC RESEARCH IN BUSINESS AND SOCIAL SCIENCES

Vol. 8, No. 8, August 2018, E-ISSN: 2222-6990 @ 2018 HRMARS

Ahmad, N. A., Kenayathulla, H. B., \& Idris, A. R. (2017). Employability Skills For Hospitality Students In Malaysia. MOJEM: Malaysian Online Journal of Educational Management, 5(4), 63-86.

Alagaraja, M., \& Arthur-Mensah, N. (2013). Exploring technical vocational education and training systems in emerging markets: A case study on Ghana. European Journal of Training and Development, 37(9), 835-850.

Ayiro, L.P. (2015). Measuring Learning Outcomes in Kenya: Context and Perspectives, In Annual Review of Comparative and International. 223-248.

Barclay, D., Higgins, C., \& Thompson, R. (1995). The Partial Least Squares (PLS) approach to causal modeling: Personal computer adoption and use as an illustration. Technology Study, 2(2), 285-309.

Bateman, A., Brown, J., \& Uera, M. (2015). Research into the financing of technical and vocational education and training (TVET) in the Pacific: Tonga: country report.

Bateman, A., Cassity, E., \& Fangalasuu, J. (2015). Research into the financing of technical and vocational education and training (TVET) in the Pacific: Solomon Islands: country report.

Becker, G. S. (1993). Nobel lecture: The economic way of looking at behavior. Journal of political economy, 101(3), 385-409.

Benson, V., Morgan, S., \& Filippaios, F. (2014). Social career management: Social media and employability skills gap. Computers in Human Behavior, 30, 519-525.

Bornemann, M., Wiedenhofer, R. (2014) Intellectual capital in education: a value chain perspective. Journal of Intellectual Capital, 15(3): 451-470.

Chin, W.W., (2001). PLS-Graph user's guide: Version 3.0. Houstan, TX: Soft Modelling.

Chude, N. P., \& Chude, D. I. (2013). Impact of government expenditure on economic growth in Nigeria. International journal of business and management review, 1(4), 64-71.

Cresswell, J.W. (1998). Qualitative Inquiry and Research Design: Choosing Among Five Traditions. London: SAGE publications.

De Guzman, A. B., \& Choi, K. O. (2013). The relations of employability skills to career adaptability among technical school students. Journal of Vocational Behavior, 82(3), 199-207.

Devkota, S. P., Chaulagain, R., \& Bagale, S. (2016). Public Expenditure In Education Sector Of Nepal. The Online Journal of New Horizons in Education, 6(2), 88-92.

Esa, A., \& Abdul Rahman, J. (2014). Tvet and strategies helping student providers into market. Journal of Education and Human Development, 3(2), 743-751.

Fan, W., Ma, Y. \& Wang, L. (2015). Do We Need More Public Investment in Higher Education? Estimating the External Returns to Higher Education in China. Asian Economic Papers, 14(3): 88-104. Fornell, C \& Larcker, D. F. (1981). Evaluating structural equation models with unobservable variables and measurement error. Journal of Marketing Research, XVIII, 39-50.

Gamlath, S. (2013). Freeing" free education in Sri Lanka, Asian Education and Development Studies, 2(1), 34-52,

Geisser, S. (1975). The predictive sample reuse method with applications. Journal of the American Statistical Association, 70, 320-328.

Gillies, D. (2017). Human Capital Theory in Education. Encyclopedia of educational philosophy and theory, 1-5.

Hair Jr, J. F., Hult, G. T. M., Ringle, C., \& Sarstedt, M. (2016). A primer on partial least squares structural equation modeling (PLS-SEM). Sage Publications.

Harris, M., Chisholm, C., \& Burns, G. (2013). Using the Knowledge Transfer Partnership approach in undergraduate education and practice-based training to encourage employer engagement. Education+ Training, 55(2), 174-190. 
INTERNATIONAL JOURNAL OF ACADEMIC RESEARCH IN BUSINESS AND SOCIAL SCIENCES

Vol. 8, No. 8, August 2018, E-ISSN: 2222-6990 @ 2018 HRMARS

Henseler, J., \& Chin, W. W. (2010). A comparison of approaches for the analysis of interaction effects between latent variables using partial least squares path modeling. Structural Equation Modeling, 17(1), 82-109.

Henseler, J., Ringle, C. M., \& Sinkovics, R. R. (2009). The use of partial least squares path modeling in international marketing. In New challenges to international marketing (pp. 277-319). Emerald Group Publishing Limited.

Ismail, S., \& Mohammed, D. S. (2015). Employability Skills in TVET Curriculum in Nigeria Federal Universities of Technology. Procedia-Social and Behavioral Sciences, 204, 73-80.

Jackson, D. (2014). Testing a model of undergraduate competence in employability skills and its implications for stakeholders. Journal of Education and Work, 27(2), 220-242.

Jeswani, S. (2016). Assessment of Employability Skills Among Fresh Engineering Graduates: A Structural Equation Modeling Approach. IUP Journal of Soft Skills, 10(2), 7-43.

Jones, S., Sutcliffe, M. J., Bragg, J., \& Harris, D. (2016). To what extent is capital expenditure in UK higher education meeting the pedagogical needs of staff and students?. Journal of Higher Education Policy and Management, 38(4), 477-489.

Kalfa, S., \& Taksa, L. (2015). Cultural capital in business higher education: reconsidering the graduate attributes movement and the focus on employability. Studies in Higher Education, 40(4), 580-595.

Kemmis, R. B., Hodge, S., \& Bowden, A. (2014). Transferable skills in technical and vocational education and training (TVET): implications for TVET teacher policies in Australia. TVET@ Asia, 3, 113.

Krskova, H. \& Baumann, C. (2017) School discipline, investment, competitiveness and mediating educational performance. International Journal of Educational Management, 31(3), 293-319.

Lee, K. S., \& Ogawa, K. (2016). Financing Technical and Vocational Education and Training in Sri Lanka. Journal Of Social Sciences And Humanities, 3(1), 27-34.

Loxley, A., Seery, A., \& Walsh, J. (2014). Investment in Education and the tests of time. Irish Educational Studies, 33(2), 173-191.

Maclean, R., \& Jagannathan, S. (2014). Introduction - Improving skills development for employability in an ever-changing world. Prospects, 44(2), 159-165.

Maglen, L., Wall, M. W., \& Rokovunisei, M. (2015). Research into the financing of technical and vocational education and training (TVET) in the Pacific: Fiji: country report.

Moses, D. (2017). Level Of Skills Acquired And Job Performance Of Graduates Of Technical Colleges In Winding Of Electrical Machines In North Eastern Nigeria. ATBU Journal of Science, Technology and Education, 5(2), 7-18.

Mulongo, G., Kitururu, I., \& Irira, M. (2016). Determinants For Positioning And Promoting Tvet In Tanzania: Information For Developing A Marketing Strategy. Journal of Technical Education and Training, 8(2), 22-37.

Nafukho, F. (2013). Capacity building through investment in people: key to Africa's development. European Journal of Training and Development, 37(7), 604-614.

Nunally, J.C., \& Bernstein, I.H. (1994). Psychometric Theory. New York: McGraw- Hill.

Ognjanović, J. (2016). Intellectual capital: Characteristics and significance in the service sector. Ekonomika, 62(3), 159-172.

Panda, S. (2015). Farmer education and household agricultural income in rural India, International Journal of Social Economics, 42(6), 514-529.

Pavlin, S., \& Svetlik, I. (2014). Employability of higher education graduates in Europe. International Journal of Manpower, 35(4), 418-424. 
INTERNATIONAL JOURNAL OF ACADEMIC RESEARCH IN BUSINESS AND SOCIAL SCIENCES Vol. 8, No. 8, August 2018, E-ISSN: 2222-6990 @ 2018 HRMARS

Rao, M. S. (2014). Enhancing employability in engineering and management students through soft skills. Industrial and Commercial Training, 46(1), 42-48.

Ridzwan, C. R., Malik, S., Hanapi, Z., Mohamed, S., Hussain, M. A., \& Shahrudin, S. (2017). Skills and Knowledge Competency of Technical and Vocational Education and Training Graduate. Asian Social Science, 13(4), 69-77.

Ringle, C. M., Wende, S., \& Will, A. (2010). Finite mixture partial least squares analysis: Methodology and numerical examples. Handbook of partial least squares, 195-218.

Sekaran, U., \& Bougie, R. (2010). Research Methods for Business: A Skill. Building Approach. UK: John Wiley.

Shirley, D. (2017). Review of Global education reform: How privatization and public investment influence education outcomes. Education Review, 24, 1-6.

Silva, J., Almeida, R., \& Strokova, V. (2015). Sustaining employment and wage gains in Brazil: A skills and jobs agenda. World Bank Publications.

Simanaviciene, Z., Giziene, V., Jasinskas, E., \& Simanavicius, A. (2015). Assessment of Investment in Higher Education: State Approach. Procedia-Social and Behavioral Sciences, 191, 336-341.

Stone, M. (1974). Cross-validatory choice and assessment of statistical predictions. Journal of the Royal Statistical Society, Series B (Methodological), 36 (2), 111-147.

Taremwa, J. (2017). Investing in Youth through TVET: An Alternative Solution to Child Trafficking and Pro-Growth Strategies in Uganda. Africa Journal of Technical and Vocational Education and Training, 2(1), 64-74.

Velasco, M. S. (2014). Do higher education institutions make a difference in competence development? A model of competence production at university. Higher Education, 68(4), 503-523.

Webster, N. S., \& Sausner, E. B. (2017). A focused analysis of TVET: unique opportunities and strategies for investing in and engaging youth in Nicaraguan society. Journal of Vocational Education \& Training, 1-22.

Yang, X. \& Huang, W. (2017). Human Capital Investment Inequality and Rural-Urban Income Gap: Evidence from China, in Cheng Few Lee, Min-Teh Yu (ed.) Advances in Pacific Basin Business Economics and Finance (Advances in Pacific Basin Business, Economics and Finance, Volume 5) Emerald Publishing Limited, 151 - 172.

York, T. T., Gibson, C., \& Rankin, S. (2015). Defining and Measuring Academic Success. Practical Assessment, Research \& Evaluation, 20(5), 1-20. 